\title{
Manufacturing and work organization: occurrences and recurrences in industrial evolution ${ }^{1}$

\author{
Michela Iannotta - Mauro Gatti
}

\begin{abstract}
Purpose of the paper: Considering the renewed interest in manufacturing, the paper offers a reinterpretation of the co-evolution between the production system and work organization in the manufacturing sector.

Methodology: The paper examines the evolution of the relationships between manufacturing and work organization through a reasoned review of the existing literature.

Findings: The article identifies the most recent discontinuities that are driving both manufacturing and work organization towards a new paradigm shift. In addition, the article contributes to the existing literature by analyzing the current debate that reveals an interesting research agenda devoted to manufacturing and work organization.

Research limits: The most visible limitation of this contribution is related to the lack of feedback on an important factor involved in the development of any industrial economic production system, the industrial policy of governments.

Practical implications: The contribution raises some issues of particular relevance about the Italian lack of innovation in work organization, which requires particular attention by Human Resources Managers.

Originality of the paper: The article offers a reinterpretation of the symbiotic evolution of manufacturing and work organization adopting the perspective of the noted philosopher Gianbattista Vico, by delineating different stages of this evolution, and by combining this with the existing literature in the two areas.
\end{abstract}

Key words: manufacturing; work organization; industrial evolution

\section{Introduction}

In manyEuropean countriestheproductivesystemisundergoing profound transformation. Italy is no exception: the manufacturing industry mirrors with exactness a long and sometimes confused transition, accompanied by uncertainties and unwillingness to confront the necessary cultural change induced by new technologies, the relentless expansion of the service sector, globalization and the intensification of competition. This transformation has frequently been bereft of adequate industrial and development policies, which would have directed the productive system along clear, well-defined

1 The paper is the result of the two authors' joint reflections. It is therefore to be attributed to both equally. 
Sinergie Vol. 33, N. 98, 2015

routes. The most tangible result of this shortcoming has been the draining of manufacturing energies towards inevitably attractive and recentlyindustrialized countries, above all, low-cost countries (Rullani, 2014). After the over-indulgence of the booming years of global finance, debate has arisen in a number of places throughout the world regarding a return to origins. Thanks to the incorporation of new mechanical, electronic and IT technologies, the manufacturing sector is returning to becoming more and more central to domestic and supranational industrial policies. Most of the recent debate indicates the existence of a real trend back towards manufacturing and, in many cases, to in-house manufacturing ${ }^{2}$. The USA heads this new tendency, a trend according to which the rising cost for labour, energy and transport in emerging countries is inducing a re-evaluation of a return home of manufacturing production (Ellram et al., 2013a, 2013b). Examples are not lacking on the European front, and much research has examined the tendencies of the so-called backreshoring (Fratocchi et al., 2014) ${ }^{3}$. Thus manufacturing is taking on a new role as an engine for growth and development, since it is able to enhance productivity and innovation at a faster pace than other economic sectors. A recent survey carried out in Italy by the Centro Studi Confindustria (2013) confirmed the positive relation between an increasing tendency in the economy towards manufacturing and greater economic growth.

This return to origins, almost a historical recurrence to coin the philosopher Vico's term, seems to cross the boundaries of post-industrial society. While present society has not negated the contribution of manufacturing over the last few decades, it does represent, however, a society no longer dependent on it (Bell, 1973). At the same time, the repositioning of manufacturing within the present productive context has led to strong elements of discontinuity with respect to its traditional configuration, to the extent of constituting a neo-industry, an emerging subject for investigation, whose features absorb the greatest changes of the twenty-first century and follow in the tracks of the service sector (Rullani, 2014). Manufacturing has in fact become social (Leng et al., 2013), digital and cloud-driven (Zhang et al., 2014; Wang, 2011) as regards variety, quality and efficiency; it approaches the consumer more and more closely in order to personalize products and it is becoming automated at an ever-increasing pace. Competition seems to be starting to diverge from the spasmodic logic of cost reduction (costs related above all to the workforce) that has accompanied delocalization policies over recent years. This route incorporates the value of knowledge and technology, environmental sustainability and research on more advanced materials.

2 The Economist (2012) has recently published a special report on manufacturing and innovation, significantly entitled A Third Industrial Revolution, underlining the impact of new technologies, above all digital technologies, on manufacturing production, and explaining the reasons behind its renewed importance for first industrialized countries. For an analysis of IT evolution towards digitalization in manufacturing see also Chryssolouris et al. (2009).

3 In Italy the footwear, textile and clothing sectors are those mainly backtracking. Among the examples of leading enterprises delocalizing back into Italy are: And Camicie, Aku, Nannini, Piquadro, Natuzzi, Wayel. 
It starts out from design, from the internet of things, automation, robotics, makers and 3D printers.

The new industrial scenario and the change in production organization

inevitably produce effects on work organization and human resources management, considering people as the most valuable resource in postindustrial capitalism. Automation, here used in the sense of technology enabling human work to be replaced by automatic process control (Bright, 1958; Crossman, 1966; Butera, 1990), drains substantial quotas of employment. New types of work and competences shape the need for a highskilled workforce. Productive flexibility requirements create new labour markets differing from traditional ones. Human resources management alternates between outsourcing and insourcing. Social recruiting appears to be the most-used tool for recruitment and compensation policies pursue integrated total reward systems.

In the light of the above, this paper intends to offer a reinterpretation of the co-evolutionary pathway that has typified production organization and labour organization in the manufacturing sector. The analytical instrument we use here is Vico's prospect of historical occurrences and recurrences; our intention is to identify the characteristic traits of industrial history and the forthcoming paradigm of change now investing both manufacturing and the organization of work.

\section{Industrial evolution and labour organization: an interdependent pathway}

After a period of progressive marginalization induced by growth potentials in the service sector, renewed interest in manufacturing is firmly rooted in those theories which believe that manufacturing can achieve a new boost to economic growth through significant increases in productivity and innovation (Kaldor, 1967, 1968; Cohen and Zysman, 1987). This almost seems a historical recourse, orienting the productive system towards a return to origins, to factories, to that material, tangible production that triggered the progress cycle in industrial society. Viewing the history and evolution of the productive system from Vico's standpoint ${ }^{4}$, this return to manufacturing would appear to make it regress after the extraordinary development following the processes of globalization, outsourcing and servitization of the economy. In fact, it is not simply a regressive cycle: this manufacturing recourse is positioned at a higher level since it capitalizes on the whole legacy left by a period of overwhelming social, economic and technological innovations, which fuelled substantial growth and well-being.

4 According to Gianbattista Vico, the history of humanity evolves through three ages: 1) the age of gods, when theocracy reigns and men submit to the revelations of auspices and oracles; 2 ) the age of heroes, featuring oligarchic regimes of the aristocracy, where power is concentrated in the hands of the mighty few; 3 ) the age of men, when intelligence and reason prevail, marked by the achievement of civil rights that made all men equal. Vico's concept of the history of humanity is that of a progressive, circular pathway; after reaching a high level of spiritual and social development, it then returns to its origins, with recourse to a second barbarian age (Berlin, 1996) 


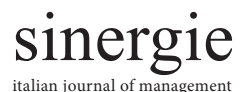
Vol. 33, N. 98, 2015

In the same way, the historical and cultural changes over the last two centuries transformed the structure and composition of factories and have favoured the rise and development of different solutions or work organization models which are redistributing action, control, decision and property rights to organizational actors (Grandori, 1999, p. 397).

This study intends to apply a new interpretative framework to classic industrial description of classifications over time, by using Vico's basic designations to account for the evolution of human history: the age of gods, the age of heroes and the age of men. In a rational attempt to interpret by analogy, our intention is to frame the role and features distinguishing the manufacturing sector in each of these productive eras and analyze the differing configurations that the organization of work in manufacturing has adopted, from the standpoint of close, natural interdependence.

\subsection{The age of gods}

A first productive age can be seen in the period covering the two industrial revolutions, when the role of manufacturing was essential in the economic and social context, a role which we might call sacred. The passage through the first to the second industrial revolution in more than a century (from 1840 to 1970) led to the emergence of different organizational paradigms that were the result of new scientific and technological paradigms that underpinned the birth of modern industry (Di Bernardo and Rullani, 1990). The widespread expansion handed down from the years of initial industrialization, growing demand and the opening up of mass markets over time, furnished a boost towards the dimensional growth of companies: thus the factory became the temple of economic development and the most tangible image of what we today define as industrial capitalism ${ }^{5}$. Growing interaction among science, techniques and the world of production has allowed us to define the second industrial revolution as the scientists' revolution (Sabatucci and Vidotto, 2008). At the same time, as a direct effect of the mechanization of the manufacturing sector, this triggered an increase in so-called technological unemployment. Due to the opening up of huge markets and to the accompanying economies of scale, the consequent enlargement of companies and mass production required firms to adopt a new organization of the productive system: this enabled organizations to achieve maximum production at minimum cost and with the minimum use of the workforce. Therefore, firms concentrated on achieving economies of scale through specialized production and standardization of both the productive processes and behaviors in manual work. The job market overflowed with poorly-qualified workers who could be classified as barely meeting what Maslow (1954) referred to as a primary needs' level.

At the same time, the availability of capital necessary to the companies to sustain the industrialization, then under way, inevitably enhanced the role of the banks, to the point that the German model is referred to as financial capitalism (Di Bernardo and Rullani, 1990). 
This scenario provided fertile ground for Frederick Taylor's scientific organization of work, an effective revolution in labour organization compared to the conditions of the previous industrial revolution. It required the complete rationalization of the work process and the identification, for each type of job, of an exact sequence of movements to ensure the highest performance with the least effort, the logic of "the one best way" in the micro-organization descriptive version. Pushed to the limit, specialization leads to the enhancement of work productivity since it continually increases efficiency in the same process and on the same product, by means of specialization and of static economies of scale. No initiative is required from the worker, nor can he act at his own discretion since the organization designer calls for a clear-cut separation between executive tasks and decisional powers (hierarchical-functional structure). The best support for work motivation in Taylor's opinion was the synthesis of two elements: discipline and economic incentives by which to bring together the interests of the worker and the entrepreneur (Fontana, 1993).

By and large, in this stage of industrial evolution, it is as if the populace lived under divine governments, and everything was commanded to them by auspices and oracles. In this sense, the oracle offered by Taylor's scientific depiction of the organization of labour answers queries regarding the present and the uncertain future of the productive process: the oracle prescribes what is scientifically the right thing to do and the best way to act in certain circumstances, so that the task completor is in no position even to think about doing anything different to what was augured. As observed in many posthumous occasions, Taylorism is a system of labour organization wherein the human being is nothing but an extension of the machine, subjected to the science of the machine.

In spite of strong criticism, Taylor's model - both at the time of its development and afterwards, was in fact the most efficient organizational solution, given the circumstances of that particular industrial age, when factory production prevailed over expanding markets and society's needs. It was to become widespread in those sectors - such as traditional mechanics and commodities in general - where stability of technology and cost-based competition could prove its worth (Grandori, 1999). The most concrete example is that of the automobile industry, where the Ford Motor Company assembly lines demonstrated a masterly application of technology-based division of labour (Sennett, 1998), and the principles of labour organization were founded on Taylorism; indeed, it became an autonomous form of production organization, Fordism itself. Fordism was to be reproduced throughout the manufacturing sector and would hold unquestioned pride of place until the mid-twentieth century.

\subsection{The age of heroes}

From the 1960s onwards, the outlines of so-called post-industrial capitalism started to take form. Daniel Bell (1973) associates with this concept the idea of an economic system no longer based on the manufacturing-industrial sector, but strongly service-oriented. As a result, in this second industrial age manufacturing lost its divine role. At the same 


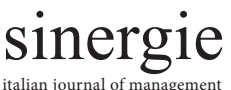
Vol. 33, N. 98, 2015

time, the organization of production and labour was punctuated by numerous elements of discontinuity. The economic crisis of 1973 (due to the sudden rise in the price of oil following the Arab-Israeli war), the threat of resources being used up, globalization processes, the growth of the service sector, the development of electronics and IT, and the increasing variety of products demanded by consumers, over time, the sum of all these factors brought about a shift in core productivity from offer to demand, from factory production towards the emerging needs of post-industrial society. The market took on a central role and became the battle-field where companies fought out to win ever-greater quotas of demand at global level. The volatility of the demand was, then, the determinant of their heroic survival.

Anticipating or creating such demand required companies to increase flexibility in their productive processes. Once more, it was a "machine" that changed the world of production (Womack et al., 1990): the Toyota Production System (Ohno, 1978) became a valid alternative to the cumbersome Fordistic productive system in limiting the risks posed by market volatility. The principles that were soon to determine the success of Toyotism also in the west were clearly in opposition to the hierarchicfunctional model of the first industrial age. These principles were lean production on demand, the involvement of employees and collaboration with suppliers, the elimination of stocks and waste, stocking products and goods just in time, and the start of total quality, where product quality is checked during all stages of the productive process. The in-house monolithic nature of organizations gradually crumbled under (strategically and economically) more suitable conditions that make the outsourcing of processing and services possible, and enable companies to focalize on core business and high value-added production, thus recuperating margins of both efficiency and effectiveness (Di Bernardo and Rullani, 1990). A contribution to the good functioning of this new production model came from the development of information technologies, through which companies were able to absorb all the advantages inherent in electronic control and remote communication. Not only that: Information technology can now enable new flatter, more flexible organization models in which co-ordination processes and the range of control modelled on the rigidly hierarchical system are reduced. In such models, the internal network form, based on semi-autonomous modules, is the first necessary step for a closer link with the external network, connecting the company to other operating units (partners, suppliers, customers, research centres), which are mainly independent from the point of view of ownership and with which the focal firm has relations of interchange and/or collaboration (Perrone, 1997). The industrial scenario progressively changed in nature, taking on the flexible specialization features described by Piore and Sabel (1984), with an assortment of specialized small and medium enterprises capable of adapting fast to change and promoting innovation mechanisms. The spread of micro and small enterprises and the development of industrial districts in Italy (Rullani, 2014) are examples of this.

Changes intervening in the production world inevitably affect labour organization. First of all, the high variance and uncertainty typical of 
this industrial era, together with the need for product differentiation and innovation, lead to an enrichment of labour organization models capable of enhancing multi-purpose capacity in the human resources used in the productive cycle (Grandori, 1999). Intervention on job rotation, job enlargement, and above all job enrichment, tend to shift the decisional pivot towards granting autonomy and some discretionary power even at lower levels, in an attempt to accelerate problem solving. Moreover, the industrial system's need for flexibility on the one hand, and the predominance of "systemic production networks" (Alter and Hage, 1992) on the other, lead to the appearance of network models even within labour organization itself. They seem to be the most effective and efficient organizational solutions in cases where specialization in single activities must combine with further variances and interdependence, or in those focusing on group comparison and social interaction, as in the Japanese model (Grandori, 1999).

At the same time, the job market changes its traditional configuration, becoming even more characterized by highly-qualified competences and high-skilled workers, mainly taken on in the service sector and white collar tasks. If technological evolution and automation now remove consistent quotas of manpower from production, on the other hand they offer workers the chance to intellectually requalify themselves in order to understand and be able to manage the working of the machine and computer-assisted manufacturing (Touraine, 1974).

To this must be added the frequent recourse to downsizing operations through which many companies in the industrial sector try to enhance their own competitiveness (Budros, 1999; Mellahi and Wilkinson, 2004) with the risk of becoming anorexic (Wilkinson, 2005). The widespread use of these processes, symbolic of a genetic mutation in capitalism towards more markedly financial horizons, leads us to wonder about their actual effects on performance in the long term (Cascio, 2002), the ability to retain knowledge within organizations (Cole, 1993), and the motivation and loyalty both of workers and consumers (Brockner, 1992; Pfeffer, 1998), areas where the correlations between these are mainly negative.

Lastly, one feature emerging from the labour market over the last few years is the dualism created among the so-called core workers who are, to a high degree, firm specific and more stable within the organization, and the peripheral workers who are employed by the company only temporarily, the latter group being heroes, nonetheless, in their efforts to govern their own employment potential. With regard to the former, organizations are able to satisfy the needs for functional flexibility required by modern manufacturing industry, while, with regards to the latter, they succeed in obtaining the numbers of workers needed for the production cycle on the basis of the demand coming from the market. The effects of this dissociation on factors such as well-being, health, job satisfaction, the commitment and engagement of temporary workers, the organizational atmosphere and the productivity of the work, in itself, have attracted the attention of numerous studies on the topic (De Witte and Näswall, 2003; Bernhard-Oettel et al., 2005; Silla et al., 2005; Virtanen et al., 2005; Kleinknecht et al., 2006). This leads us to reflect that it may be opportune to find alternative instruments with which to sustain production elasticity, as shown by copious papers 
sinergie Vol. 33, N. 98, 2015

on the subject of manufacturing flexibility (Donald, 1993; Vokurka and O’Leary-Kelly, 2000; Urtasun-Alonsoa et al., 2014; Kaur, 2014).

The twentieth century ended with a low-growth state of affairs, evident above all in Italy where incapacity to innovate, the fall in production, the limits of 'made in Italy' products and the negative values of productivity (Ciocca, 2007) increase the effects of a blocked economy and a stalemate phase in many parts of the world.

\subsection{The age of men}

In this third industrial age, the traditional borderline between manufacturing and service sectors fades away and we see the rise of neo-industry accompanying mass production, yet diverging from it in a number of specific features (Rullani, 2014). Off-shoring processes and the downsizing of activities are still in progress and involve those manufacturing plants where the leading strategy and cost-reduction rationale mainly coincide. The relative knowledge is highly coded and focuses on the lowest added value elements in the value chain; activities related to this are easily replicated in low-cost countries (Rullani, 2014).

In the meantime, the relentless evolution of ICT and Internet has radically changed means of communication in everyday life (Wood and Smith, 2001); Wellman et al., 2001), with and within organizations (Markus and Robey, 1988; Galliers and Beats, 1998; Stevens et al., 2000). New challenges and new opportunities thus arise both in the world of manufacturing production and in that of human resources management and work organization. The digital revolution and the now visible role of knowledge in the new economy (Rullani, 2004) have become distinctive features of what is today called networking capitalism, through which knowledge is spread to fuel new ways of producing and consuming (Rullani, 2008). The network becomes not only the dominant organizational form (Alter and Hage, 1992), but it also takes on an effectively central role in the changed economic-social context. Through webs of relations that concentrate and facilitate the flow of information, individuals, consumers and businesses therefore form ties and find themselves ideally on a level in connection with each other. Thanks to the social media (blogs, wiki, e-mail, text messaging, social networks), barriers to social interaction are lowered and connections are activated that could not otherwise come about (Gravili, 2011). This is the age of men, in which all men recognized themselves as equal in human nature (Vico, 1744, p. 27) and in which intelligence and reason enlighten minds. Man becomes the central nerve of this vast population of networks, being for once and at the same time consumer, worker, producer and inventor.

Production increasingly addresses the customer in an effort to supply him with personalized and diversified products. The role of marketing becomes more and more relational and interactive in order to create a thread constantly binding production to the network, or rather, binding the network of producers to that of the consumers (Di Bernardo and Rullani, 1990). The internet of things revolutionizes the traceability of productive processes, enhancing their precision and promptness (Schlick 
et al., 2012). By means of knowledge sharing through the web, open sources and new I.T. technologies, anyone can become a maker, a digital craftsman materializing his own products through laser cutting machines and $3 \mathrm{D}$ printers (Anderson, 2012). The hypothesis of a return to the ideal of a romantic craftsman seems to make plausible the mid-nineteenth century utopian vision of John Ruskin (1851-1853). Ruskin imagined a project designer who momentarily loses control of his own work, struggling upstream against an overwhelming flow rushing towards the dominion of machines, refusing the present, he recalls the past to look to the future (Sennet, 2008, pp. 107-118). In present day terms, the formation of the online community that can offer 3D printers and other services for production presupposes the rapid development of a new phenomenon called social manufacturing (The Economist, 2012, p. 2) ${ }^{6}$.

The dematerialization of manufacturing is accompanied by the industrialization of the third sector, now capable of offering standardized services through the use of replication technologies that make possible increased volumes and reduced replication costs (Rullani, 2014). The sectors of personal care services and business services absorb a large proportion of the workforce, while in manufacturing plants robotized automation becomes more and more widespread ${ }^{7}$, to the point of no longer requiring any human intervention except for reprogramming moves. As a result, a higher "threshold competence" is required to operate in modern factories; both for the country's economic system and for each single enterprise, it is therefore needful to reconsider training and education policies to identify innovative formulae for the evaluation of human capital based on closer cooperation among institutions, businesses, universities and research centres, in line with the new requirements of manufacturing knowledge. Once again, following the logic of Touraine (1974), we are facing an intellectual requalification of people towards the machine, and this will lead to ever rising employment in the robot and mechatronic sectors.

Regarding labour organization, practices with the prefix high performance are becoming more and more common, shortened into acronyms such as: HPWS (high performance work system), HPWO (high performance work organization) and HPWP (high performance work practices) (Huselid, 1995). These are an integrated group of work practices belonging to three large areas. The first concerns the involvement of employees with

6 The Economist (2012:2) writes: "As manufacturing goes digital, a third great change is now gathering pace. It will allow things to be made economically in much smaller numbers, more flexibly and with a much lower input of labour, thanks to new materials, completely new processes such as 3D printing, easy-touse robots and new collaborative manufacturing services available online. The wheel is almost coming full circle, turning away from mass manufacturing and towards much more individualised production. And that in turn could bring some of the jobs back to rich countries that long ago lost them to the emerging world".

7 McKinsey \& Company (2013) attempts to quantify the potential effects of these technologies on the economy by 2025: advanced robotics and 3D printers will impact on approximately 320 million workers in the manufacturing industry (12\% of the global workforce) compared with a $170 \%$ growth of sales of industrial robots between 2009 and 2011 and with the increase in profits in additive manufacturing revenue by four times as much.
Michela Iannotta

Mauro Gatti

Manufacturing and work organization:

occurrences and

recurrences in industrial evolution 
sinergie Vol. 33, N. 98, 2015

procedures, encouraging trust and communications between employer and employees. Such practices aim to render responsible employees by granting them greater decisional power and control over their own work. In turn, this leads to greater motivation, leadership, communications and team work. Typical practices include self-managing teams, quality circles and a higher share in or access to company information, particularly that related to strategies under way. The second area concerns Human Resources Management (HRM) practices focusing on investments in human capital and development of competence within the organization. The third area considers the rewarding issue, with practices aiming to create a sense of commitment towards the organization. Financial rewards such as participation in profits and options aim to build a sense of belonging to the company, while the pay-for-performance formula tends to enhance commitment and encourage higher performance.

Such practices are often associated with production management policies orientated towards total quality management, world-class manufacturing and the co-related reasons of lean production.

Human resources management practices with a high level of worker involvement, the efficient organization of productive processes, the presence of good industrial relations and the use of ICT technologies therefore represent the new frontiers of labour organization which, combined together in various ways, lead to higher performance; this has also been confirmed by econometric studies (e.g. Leoni, 2013).

Hence if the world of production is shifting towards the end, consumer, personnel management policies centre on their direct clients, i.e., human resources themselves: according to the Resource-Based View (Penrose, 1959; Barney, 2001), this is a key factor for the firm's competitive advantage. From a relational viewpoint, the firm listens to the needs and requests from its own workforce. The satisfaction of such expectations makes the workers feel more committed, involved and acknowledged in their organization, with evident repercussions on motivation and satisfaction, and so on work performance. Care for people thus triggers individual activation mechanisms that induce the workers to operate in the real interest of the organization (Bergami, 1996). Total reward pay policies and advanced HRM systems, for example, come within this logic (Urtasun-Alonso et al., 2014) introducing space-time flexibility instruments that will aid workers to reconcile their private life with their job. Through the introduction of flexible hours, a reduced working week, teleworking and working time accounts, positive effects can be achieved on productivity, individual performance, commitment, organization performance and job satisfaction (e.g., Orpen, 1981; Pierce and Newstrom, 1983; McCampbell, 1996; Scandura and Lankau, 1997; Dex and Scheibl, 1999; Glass and Finley, 2002; Kauffeld et al., 2004; Stavrou, 2005; Martinez-Sanchez et al., 2007), as well as obvious improvements in family-job balance and health (Brough et al., 2005; Halpern, 2005; Thomas and Ganster, 1995; Kelliher and Anderson, 2008). The role of Human Resource Management becomes that of a business partner in the development and implementation of business strategies. This requires a (long-term) strategic vision of human resources rather than an approach 
addressing short-term operative cost reductions. Lastly, as we see once again on production lines for certain work processes or in some services, many procedures typical of Human Resources (HR) tasking are also frequently outsourced (Grundy, 1998; Lever, 1997; Klaas et al., 1998), as in the case of the management of the so-called "peripheral" workers (Kosnik et al., 2006).

The drift of this third industrial age has not yet reached its peak; its evolution leaves in its wake a scenario which is both composite and intricate. The high connectivity of the economic and social system and the digital revolution offer both challenges and new opportunities; this connectivity is claimed by many to be the key to boosting economic growth, but, as yet, it is merely creeping forward.

\section{The return to manufacturing in Italy: what kind of labour organization?}

The long-lasting economic stagnation of the last few years has focused attention on possible strategies to employ in order to give new impulse to economic development. As mentioned above, the European productive system has undergone a phase of profound transformation. In the case of Italy, this has not been accompanied by adequate industrial policies capable of steering the productive system in one single, clear direction. According to the Istat Report on Competitiveness in Productive Sectors (2014), the impact of the crisis on industrial production in the European countries has been highly diversified. Unlike Germany, France and the United Kingdom, Italy has lost approximately one quarter of its industrial product, especially in the sector of durable goods. The empirical analysis in the Report shows a notable dichotomy in the strategy/performance ratio, with the result that firms with more limited (or "losing") performances have tended to downsize their activity and defend their own market share; the "winners", meanwhile, have participated in process and product innovation, investments in human capital and training and substantial productive relations with various parties (partnerships and joint ventures, consortia, networks). In particular, the successful defence of productive potential has mainly involved qualified human resources, with the result that growing unemployment has affected the less qualified part of the workforce.

This overview is accompanied by a growing tendency to re-import inhouse manufacturing, seen as much in the United States (Ellram et al., 2013a, 2013b; Tate, 2014) as in certain European economies, Italy among them (Kinkel and Maloca, 2009; Kinkel, 2012; Fratocchi et al., 2014). We will deal further with this subject below. It is now commonly held that reasons for back-reshoring are mainly based on changing strategies in the industrial sector, which now appears for the most part to be orientated towards innovative, high-quality manufacturing. And there is more to this: after a period strongly oriented towards the third sector in the economy and the service sector in industry, the most recent discussions focus on the need for a real return to manufacturing and the re-industrialization of the economic system. Such convictions are supported by the productivity and innovation differential that manufacturing is capable of generating,
Michela Iannotta

Mauro Gatti

Manufacturing and work organization:

occurrences and

recurrences in industrial evolution

\author{
.
}


sinergie Vol. 33, N. 98, 2015

unlike the third sector, which is considered less productive (Kaldor, 1967, 1968; Baumol, 1985; Cohen and Zysman, 1987); this would confirm the existence of a positive relation between more manufacturing in the economy and greater economic growth. This relation, furthermore, seems stronger in more advanced countries, given that a $1 \%$ increase in the manufacturing quota of the overall economy corresponds to a $1.5 \%$ growth in GDP, compared to a growth of $0.5 \%$ in the so-called "lagging" countries (CSC, 2013).

The sense of this manufacturing recourse lies in the intention to return the economic system to its origins, to a tangible production that is also capable of bringing about an increase in employment, which, for too long now, has been draining off towards emerging countries. Continuing in our reasoning along Vico's lines, it is not, however, a simple regression towards a "second barbarity", since in having recourse to its origins, our industrial system finds itself enriched by all those social, economic and technologic innovations which have so far marked its progress. From this angle, we glimpse a composite system and enriched traditional manufacturing where additive manufacturing will multiply as the outcome of the revolution of new makers and 3D printers. This will fuel a constellation of outstandingly innovative small and micro enterprises.

In this forthcoming scenario, work organization will have to ponder its contribution to both the former and the latter type of manufacturing. Moreover, in taking manufacturing to its tangible origins, work organization will have to arm itself with the most innovative features achieved in the last few years; it will have to be the main support of productivity increases on capital invested. In this regard, and in spite of the achievements reached by the most recent systems of human resources management (HPWS, HPWO, HPWP, WCM), Italy is particularly reticent in innovating its own work organization (Pini, 2013). A survey carried out by Eurofound ${ }^{8}$ (2011) draws attention to the fact that Italy is among the slowest in adopting innovative work practices, i.e., human resources management policies (flexible working hours, performancebased pay, training, using work squads with autonomous decisional powers, involving the workers and their representatives). Such policies produce results in terms of the atmosphere in the workplace, lack of issues in managing human resources, economic performance and productivity. In $51 \%$ of cases, Italy adopts none of these practices, in $32 \%$ at least one, and only in $17 \%$ of cases at least two. Such data reflect the evident lagging behind of our productive system.

\section{Discussion and Implications}

Many parties in the international economic context are calling for a return to manufacturing, as the first experiences of back-reshoring show. This implies a visible re-think of industrial strategies by the countries involved. This return, however, is grafted onto a tissue of discontinuities

8 The survey was carried out in 27,000 workplaces (industries and services) in 30 countries. 
which during this new millennium have posed, and will in the foreseeable future continue to pose, challenges to face and opportunities to seize. In its development, the present paper has described the interdependent evolution found in production and work organization over these centuries of economic progress. An age of a more human modernity having been reached, the challenge is to maximize any industrial recourse to manufacturing as a new starting point to innovate substantial and widespread work organization in our factories. In the light of this challenge, reflection on Italy's present position in comparison with other advanced economies is required. Haphazard dispersion of innovative work practices that would conflict with the egalitarian logic of a fully integrated network system needs to be avoided.

In particular, if the aim is to increase productivity in order to boost economic growth, then this productivity should return to the places of production, to the factories where people represent in flesh and blood those acclaimed work units which measure the quantity of product obtained. From an analysis of the literature carried out up to this point, various elements emerge on which to base the renewal of work organization and human resources management: 1) the implementation of instruments of space-time flexibility in order to achieve a positive effect on productivity, individual and organization performance, job satisfaction and worker commitment; 2) pay policies orientated towards total reward and the offer of company welfare services impacting on the specific tendency of individuals to feel more satisfied, involved, committed and recognized in the organization for which they work; 3) advanced HRM systems (flexible work, decisional autonomy for work groups, high communication levels, intensive training, fair treatment at all organization levels) are positively associated with higher performance and greater flexibility of the manufacturing industry.

\section{Conclusions, limitations and future research}

This paper offers a new reading of the historical evolution of production organization and work organization in the manufacturing sector in the light of Vico's approach. Through a careful analysis of the literature, it also helps to identify those factors that have enriched both, featuring strong elements of discontinuity over time, as well as the potential points of leverage on which to act in the near future, prompting a new boost to competitiveness in manufacturing firms on the one hand, and work productivity on the other. Lastly, the article contributes to the existing literature on the subject through a reflective analysis on the debate underway today, while posing a number of questions which require consideration both by the organizations and the human resources managers.

From the analysis carried out, it seems that innovation in work organization is only one of the points of leverage to be used to boost Italian manufacturing, especially given the many incongruities and contradictions which continue to exist in our country. As stressed in the Confindustria's report on industrial scenarios, whereas manufacturing in the world continues to expand, in Italy production is contracting (CSC, 2014), with a loss of approximately 120,000 firms and of more than a million employees
Michela Iannotta
Mauro Gatti

Manufacturing and work organization:

occurrences and

recurrences in industrial evolution 
sinergie Vol. 33, N. 98, 2015

between 2001 and 2013. The high cost of labour per unit of output also penalizes our industry: manufacturing productivity contracted by up to $2.4 \%$ between 2012 and 2013, while the 2013 cost of labour per unit of output exceeded the 2007 figures by $20.7 \%$. In spite of the fact that exports have tended to remain stable during the crisis years, the fall in domestic demand, together with the increasing difficulty of companies to obtain financing from the credit system, are obstacles of no small impediment in re-launching our economy.

These figures would seem to be totally incompatible and at odds with the overall purpose our study investigates, that of re-evaluating the manufacturing sector as the engine for recovery and, above all, for growth of the economic system. This non-alignment probably reflects dysfunction in industrial policies over the last twenty years, both in Europe and in Italy. The lack of an organic, unanimous response to competitiveness and productivity issues in Italy is partly responsible for certain features: industries with no will to upsize; groups of firms that are notably innovative and productive yet frequently isolated; and manufacturing that moves off-shore towards emerging countries. This has all contributed to the dispersion of the in-house knowledge acquired and, last but not least, to the on-going erosion of employment levels with frequent recourse to the unemployment benefits provided by the Italian insurance system (e.g., "Cassa Integrazione Guadagni”). However, the proposals of the political and economic world in Italy, together with a new strategy for the much delayed industrial policy adopted by the European Union as of 2010, would appear to indicate an important change of direction. Primary aims are therefore the identification of the industrial sectors on which to focus in the near future, a social intervention plan to give a new start to consumption flows, which will hopefully support production increase and a stronger link with the territory through domestic demand. The intention is to work towards productive territorial specialization in order to recover ground in terms of the competitive advantage lost by our firms over recent years (CSC, 2014).

As well as presenting a descriptive analysis, the most evident limitation of the present paper is its failure to assess an important factor involving the industrial evolution of any economic/productive system: the country's industrial policy. In the future, we intend to incorporate this into our approach in order to obtain a more complete and thorough evolving picture.

In conclusion, the rising demand for a return to manufacturing, together with the need to innovate our work organization systems, promises yet more fertile ground for an agenda regarding research on manufacturing and manufacturing labour. It is above all for this reason that we look forward to a more detailed analysis, especially accompanied by empirical work, of this phenomenon within our productive context in order to increase the awareness of those managing human resources and of those leading decision-making in the world of Italian industry. 


\section{References}

ALTER C., HAGE J. (1992), Organizations Working Together. Coordination in Interorganizational Networks, Sage, Newbury Park, California.

ANDERSON C. (2012), Makers. The New Industrial Revolution, Crown Business, New York.

BARNEY J.B. (2001), "Is the resource-based «view» a useful perspective for strategic management research? Yes", Academy of Management Review, vol. 26, n. 1, pp. $41-56$

BAUMOL W.J. (1985), "Productivity policy and the service sector", in Inman R.P. (ed. by), Managing the Service Economy: Prospects and Problems, Cambridge University Press, London, pp. 301-337.

BELL D. ( 1973), The Coming of Post-Industrial Society: A Venture in Social Forecasting, Basic Books, New York.

BERLIN I. (1996), Le idee filosofiche di Giambattista Vico, Armando Editore, Roma. BERGAMI M. (1996), L'identificazione con l'impresa, NIS, Roma.

BERNHARD-OETTEL C., SVERKE M., DE WITTE H. (2005), “Comparing three alternative types of employment with permanent full-time work: How do employment contract and perceived job conditions relate to health complaints?", Work and Stress, vol. 19, n. 4, pp. 301-318.

BRIGHT J.R. (1958), Automation and Management, Harvard University, Cambridge. BROCKNER J. (1992), "Managing the effects of lay-offs on survivors", California Management Review, vol. 34, n. 2, pp. 9-28.

BROUGH P., O'DRISCOLL M., KALLIATH T. (2005), “The ability of familyfriendly organizational resources to predict work-family conflict and job and family satisfaction", Stress and Health, vol. 21, n. 4, pp. 223-234.

BUDROS A. (1999), "A conceptual framework for analyzing why organizations downsize", Organization Science, vol. 10, n. 1, pp. 69-82.

BUTERA F. (1990), Il castello e la rete: impresa, organizzazione e professioni nell'Europa degli anni'90, Franco Angeli, Milano.

CASCIO F.W. (2002), "Strategies for responsible restructuring", Academy of Management Executive, vol. 16, n. 3, pp. 80-91.

CENTRO STUDI CONFINDUSTRIA (2013), Lalto prezzo della crisi per l'Italia. Crescono i paesi che costruiscono le condizioni per lo sviluppo manifatturiero, Sipi S.p.A, Roma.

CENTRO STUDI CONFINDUSTRIA (2014), In Italia la manifattura si restringe. Nei Paesi avanzati le politiche industriali puntano sul territorio, Sipi S.p.A, Roma.

CHRYSSOLOURIS G., MAVRIKIOS D., PAPAKOSTAS N., MOURTZIS D., MICHALOS G., GEORGOULIAS K. (2009), "Digital Manufacturing: History, Perspectives, and Outlook”, Proc. IMechE, vol. 223, Part B: Engineering Manufacture, pp. 451-462.

CIOCCA P. (2007), Ricchi per sempre? Una storia economica d'Italia (1796-2005), Bollati Boringhieri, Torino.

COHEN S.S., ZYSMAN J. (1987), Manufacturing Matters. The Myth of the PostIndustrial Economy, Basic Books, New York.

COLE R. (1993), "Learning from learning theory", Quality Management Journal, vol. 1, n. 1, pp. 9-25.

CROSSMAN E.R. (1966), Taxonomy of automation, Oecd, Paris.
Michela Iannotta

Mauro Gatti

Manufacturing and work

organization:

occurrences and

recurrences in industrial evolution 
sinergie Vol. 33, N. 98, 2015

DE WITTE H., NÄSWALL K. (2003), “Objective vs Subjective Job Insecurity: Consequences of Temporary Work for Job Satisfaction and Organizational Commitment in Four European Countries", Economic and Industrial Democracy, vol. 24, n. 2, pp. 149-188.

DEX S., SCHEIBL F. (1999), "Business performance and family-friendly policies", Journal of General Management, vol. 24, n. 4, pp. 22-37.

DI BERNARDO B., RULLANI E. (1990), Il management e le macchine, Il Mulino, Bologna.

DONALD G. (1993), "Manufacturing flexibility: A strategic perspective", Management Science, vol. 39, n. 4, pp. 395-410.

ELLRAM L.M., TATE W.L., FEITZINGE E.G. (2013a), "Factor market rivalry and competition for supply chain resources", Journal of Supply Chain Management, vol. 49, n. 1, pp. 29-46.

ELLRAM L.M., TATE W.L., PETERSEN K.J. (2013b), “Offshoring and reshoring: an update on the manufacturing location decision", Journal of Supply Chain Management, vol. 49, n. 2, pp. 14-22.

EUROFOUND (2011), HRM Practices and Establishment Performance, Eurofound, Dublino, Available at: http://www.eurofound.europa.eu/ publications/report/2012/labour-market-business/hrm-practices-andestablishment-performance-an-analysis-using-the-european-companysurvey-2009

FONTANA F. (1993), Il sistema organizzativo aziendale, Franco Angeli, Milano.

FRATOCCHI L., DI MAURO C., BARBIERI P., NASSIMBENI G., ZANONI A. (2014), "When manufacturing moves back: Concepts and questions", Journal of Purchasing and Supply Management, vol. 20, n.1, pp. 54-59.

GALLIERS R.D., BAETS W.R.J. (1998), Information Technologyand Organizational Transformation: Innovation for the 21st Century Organization, John Wiley \& Sons, Chichester.

GLASS J., FINLEY A. (2002), "Coverage and effectiveness of family-responsive workplace policies”, Human Resource Management Review, vol. 12, n. 3, pp. 313-337.

GRANDORI A. (1999), Organizzazione e comportamento economico, Il Mulino, Bologna.

GRAVILI G. (2011), Il social recruiting, Cacucci Editore, Bari.

GRUNDY T. (1998), "How are corporate strategy and human resources strategy linked?”, Journal of General Management, vol. 23, n. 3, pp. 49-72.

HALPERN D. (2005), "How time-flexible work practices can reduce stress, improve health and save money", Stress and Health, vol. 21, n. 3, pp. 157168.

HUSELID M. (1995), "The impact of human resource management practices on turnover, productivity, and corporate financial performance", Academy of Management Journal, vol. 38, n. 3, pp. 635-672.

ISTAT (2014), Rapporto sulla competitività dei settori produttivi, Stealth, Roma.

KALDOR N. (1967), Strategic Factors in Economic Development, Cornell University Press, Ithaca.

KALDOR N. (1968), "Productivity and Growth in Manufacturing Industry: A Reply", Economica, vol. 35, n. 140, pp. 385-91. 
KAUFFELD S., JONAS E., FREY D. (2004), "Effects of a flexible work-time design on employee and company related aims", European Journal of Work and Organizational Psychology, vol. 13, n. 1, pp. 79-100.

KAUR R. (2014), "A Study of Human Resource Practices of Employees in Manufacturing Industry at Punjab", International Monthly Refereed Journal of Research In Management and Technology, vol. 3, n. 2, pp. 40-44.

KELLIHER C., ANDERSON D. (2008), "For Better or for Worse?: an analysis of how flexible working practices influence employees' perceptions of job quality", International Journal of Human Resource Management, vol. 19, n. 3, pp. 419431.

KINKEL S. (2012), "Trends in production relocation and back-shoring activities: changing patterns in the course of the global economic crisis", International Journal of Operations and Production Management, vol. 32, n. 6, pp. 696-720.

KINKEL S., MALOCA S.(2009), "Drivers and antecedents of manufacturing offshoring and back shoring - a German perspective", Journal of Purchasing and Supply Management, vol. 15, n. 3, pp. 154-165.

KLAAS B.S., MCCLENDON J., GAINEY T.W. (1998), "HR outsourcing and its impact: the role of transaction costs", Personnel Psychology, vol. 52, n. 1, pp. 113-137.

KLEINKNECHT A., OOSTENDORP R.M., PRADHAN M.P., NAASTEPAD C.W.M. (2006), "Flexible Labour, Firm Performance and the Dutch Job Creation Miracle", International Review of Applied Economics, vol. 20, n. 2, pp. 171-187.

KOSNIK T., WONG-MINGJI D.J., HOOVER K. (2006), "Outsourcing vs insourcing in the human resource supply chain: a comparison of five generic models", Personnel Review, vol. 35, n. 6, pp. 671-683.

LENG J., JIANG P., ZHANG F., CAO W. (2013), "Framework and Key Enabling Technologies for Social Manufacturing", Applied Mechanics and Materials, vol. 312, n. 4, pp. 498-501.

LEONI R. (2013), "Organization of work practices and productivity: an assessment of research on world - class manufacturing", in Grandori A. (ed.), Handbook of Economic Organization. Integrating Economic and Organization Theory, Edward Elgar, Cheltenham.

LEVER S. (1997), "An analysis of managerial motivations behind outsourcing practices in human resources", Human Resource Planning, vol. 20, n. 2, pp. 37-47.

MARKUS M.L., ROBEY D. (1988), "Information Technology and Organizational Change: Casual Structure in Theory and Research", Management Science, vol. 34, n. 5, pp. 583-598

MARTINEZ-SANCHEZ A., PEREZ-PEREZ M., LUIS-CARNICER P., VELAJIMENEZ M. (2007), "Telework, human resource flexibility and firm performance", New Technology, Work and Performance, vol. 22, n. 3, pp. 208223.

MASLOW A. (1954), Motivation and Personality, Harper \& Row, New York.

MCKINSEY \& COMPANY (2013), "Disruptive technologies: Advances that will transform life, business, and the global economy", McKinsey Global Institute, May 2013.

MCCAMPBELL A. (1996), "Benefits achieved through alternative work schedules", Human Resource Planning, vol. 19, n. 3, pp. 30-37.
Michela Iannotta

Mauro Gatti

Manufacturing and work

organization:

occurrences and

recurrences in industrial

evolution 
sinergie Vol. 33, N. 98, 2015

MELLAHI K., WILKINSON A. (2004), "Downsizing and Innovation Output: A Review of Literature and Research Propositions", Paper presented at British Academy of Management Conference, St Andrews, September 2004.

OHNO T. (1988), "Toyota Production System: Beyond Large - Scale Production”, Productivity Press, Cambridge, Mass. Translation by Ohno T. (1978) Toyota seisan hoshiki, Diamond, Tokyo.

ORPEN C. (1981), "Effect of flexible working hours on employee satisfaction and performance: A field experiment", Journal of Applied Psychology, vol. 66, n. 1, pp. 113-115.

PENROSE E. (1959), The theory of the growth of the firm, Wiley, New York.

PERRONE V. (1997), "La rete", in Costa G., Nacamulli R.C.D., (ed. by), Manuale di Organizzazione Aziendale, II Volume, La Progettazione Organizzativa, Utet, Turin.

PFEFFER J. (1998), The Human Equation, Harvard Business School Press, New York.

PIERCE J.L., NEWSTROM J.W. (1983), “The design of flexible work schedules and employee responses: relationships and process", Journal of Occupational Behavior, vol. 4, n. 4, pp. 247-262.

PINI P. (2013), "Quell'organizzazione del lavoro che non cambia", Lavoce.info, Fonte web: http://www.lavoce.info/quellorganizzazione-del-lavoro-chelitalia-non-innova/

PIORE M., SABEL F. (1984), The Second Industrial Digital Divide: Possibilities for prosperity, Basic Books, New York.

RULLANI E. (2004), Economia della conoscenza. Creatività e valore nel capitalismo delle reti, Carocci, Roma.

RULLANI E. (2008), "L'economia della conoscenza nel capitalismo delle reti", Sinergie, n. 76, pp. 67-90.

RULLANI E. (2014), "Manifattura in transizione”, Sinergie, n. 93, pp. 141-152.

RUSKIN J. (2003), The Stones of Venice [1851-1853], Da Capo Press, New York.

SABATUCCI G., VIDOTTO V. (2008), Il mondo contemporaneo. Dal 1848 a oggi, Laterza, Roma.

SCANDURA T., LANKAU M. (1997), "Relationships of gender, family responsibility and flexible work hours to organizational commitment and job satisfaction", Journal of Organizational Behavior, vol. 18, n. 4, pp. 377 391.

SCHLICK J., STEPHAN P., ZUHLKE D. (2012), "Manufacturing 2020 - Towards a fourth Industrial Revolution", Information Management and Consulting, vol. 27, n. 3, pp. 26-33.

SENNETT R. (1998), The Corrosion of Character. The Personal Consequences of Work in the New Capitalism, W.W. Norton \& Company, New York.

SENNETT R. (2008), “The Craftsman”, Yale University Press, New Haven and London, (It. trans., L'uomo artigiano, Feltrinelli, Milano, III ed., 2009).

SILLA I., GRACIA F.J., PEIRÓ J.M. (2005), "Job insecurity and health-related outcomes among different types of temporary workers", Economic and Industrial Democracy, vol. 26, n. 1, pp. 89-117.

STAVROU E.T. (2005), "Flexible work bundles and organizational competitiveness: A cross-national study of the European work context", Journal of Organizational Behaviour, vol. 26, n. 8, pp. 923-947. 
STEVENS P.M., WILLIAMS K.P., SMITH M.C. (2000), "Organizational Communication and Information Processes in an Internet-Enabled Environment", Psychology and Marketing, vol. 17, n. 7, pp. 607-632.

TATE W.L. (2014), "Offshoring and reshoring: U.S. insights and research challenges", Journal of Purchasing and Supply Management, vol. 20, n. 1, pp. 66-68.

THE ECONOMIST (2012), Manufacturing And Innovation, Special Report (ed. by Markillie P.), April 21st, pp. 1-14.

THOMAS L.T., GANSTER D.C. (1995), "Impact of family-supportive work variables on work-family conflict and strain: A control perspective", Journal of Applied Psychology, vol. 80, n. 1, pp. 6-15.

TOURAINE A. (1974), Levoluzione del lavoro operaio alla Renault, Rosenberg \& Sellier, Turin (original ed. Paris, 1955).

URTASUN-ALONSOA A., LARRAZA-KINTANAA M., GARCÍA-OLAVERRIB C., HUERTA-ARRIBAS E. (2014), "Manufacturing flexibility and advanced human resource management practices”, Production Planning and Control, vol. 25 , n. 4 , pp. 303-317.

VICO G. (1744), Principi di Scienza Nuova d'intorno alla comune natura delle nazioni, in questa terza impressione dal medesimo autore in più luoghi corretta, schiarita e notabilmente accresciuta, Tomo I, Naples.

VIRTANEN M., KIVIMÄKI M., JOENSUU M., VIRTANEN P., ELOVAINIO M., VAHTERA J. (2005). “Temporary employment and health: a review", International Journal of Epidemiology, vol. 34, n. 3, pp. 610-622.

VOKURKA R.J., O'LEARY-KELLY S.W. (2000), "A review of empirical research on manufacturing flexibility”, Journal of Operations Management, vol. 18, n. 4, pp. 485-501.

WANG L. (2011), "Planning towards enhanced adaptability in digital manufacturing", International Journal of Computer Integrated Manufacturing, vol. 24, n. 5, pp. 378-390.

WELLMAN B., WITTE J., HAMPTON K. (2001), "Does the Internet Increase, Decrease, or Supplement Social Capital? Social Networks, Participation, and Community Commitment", American Behavioral Scientist, vol. 45, n. 3, pp. 436-455.

WILKINSON A. (2005), "Downsizing, Rightsizing or Dumbsizing? Quality, Human Resources and the Management of Sustainability", Total Quality Management, vol. 16, n. 8-9, pp. 1079-1088.

WOMACK J.P., JONES D.T., ROOS D. (1990), The Machine That Changed the World: The Story of Lean Production, Rawson Associates Scribner, Simon \& Schuster Inc., New York.

WOOD A.F., SMITH M.J. (2001), Online Communication: Linking technology, Identity, and Culture, Lowrence Erlbaum Associates, Mahwah, NJ.

ZHANG L., LUO Y., TAO F., HU LI B., REN L., ZHANG X., GUO H., CHENG Y., HU A., LIU Y. (2014), "Cloud manufacturing: a new manufacturing paradigm”, Enterprise Information Systems, vol. 8, n. 2, pp. 167-187.
Michela Iannotta

Mauro Gatti

Manufacturing and work organization: occurrences and recurrences in industrial evolution 


\section{sinergie}

italian journal of management Vol. 33, N. 98, 2015

\section{Academic or professional position and contacts}

\section{Michela Iannotta}

$\mathrm{PhD}$ Candidate in Management, Banking and Commodity Sciences

Sapienza University of Roma - Italy

e-mail:michela.iannotta@uniroma1.it

\section{Mauro Gatti}

Full Professor of Organization Studies

Sapienza University of Roma - Italy

e-mail: mauro.gatti@uniroma1.it

sinergie italian journal of management ISSN 0393-5108 DOI 10.7433/s98.2015.08 pp. $105-124$

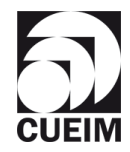

